\title{
河川感潮域に整備された緩勾配河岸の 底生生物による評価 \\ EVALUATION BY BENTHOS OF THE GENTLE SLOPE REVETMENT WHICH WAS PROVIDED IN A TIDAL RIVER
}

\author{
高比良光治 ${ }^{1} \cdot$ 島谷幸宏 $2 \cdot$ 深津慎司 $^{3} \cdot$ 金原絵理子 4 -中島淳 5 \\ 池松伸也 6 ・河口洋一7 \\ Koji TAKAHIRA, Shimatani YUKIHIRO, Shinji FUKATSU, Eriko KINBARA, \\ Jun NAKAJIMA, Shinya IKEMATSU and Yoichi KAWAGUCHI \\ 1学生会員 九州大学大学院工学府（干819-0395 福岡市西区元岡744） \\ 2フェロー会員 工博 九州大学大学院工学研究院（广819-0395 福岡市西区元岡744） \\ 3非会員 東京都建設局（干163-8001 東京都新宿区西新宿2-8-1） \\ 4非会員 無職 \\ 5非会員 農博 福岡県保健環境研究所（T818-0135 太宰府市大字向佐野39） \\ 6正会員 九州大学大学院工学府（†819-0395 福岡市西区元岡744） \\ 7正会員 学術博 徳島大学大学院ソシオテクノサイエンス研究部（†770-8506 徳島市南常三島2-1）
}

\begin{abstract}
In order to grasp the effect of the gentle slope revetment works to exert on the biodiversity at a tidal river, we surveyed at the tidal area in the Gokase River in Miyazaki Prefecture about the distributions of physical environments (ground levels, grain diameter and ignition loss of bed material) and the benthic communities at both of the soil-covered gentle slope revetment (A), and the vertical dry stone pitching revetment (B).

As the results, the physical environments were similar in a transverse direction at the B section but the A section were successively varied. The kinds, and rare species of benthos, especially insects were rich at the A section rather than the B section. The results suggested that the gentle slope revetment works had improved biodiversity.
\end{abstract}

Key Words : gentle slope revetment, tidal river, benthos, Gokase River

\section{1. はじめに}

多自然型川づくりは，1990年に始まって以来，日本全 国において実践されてきたが1)，その一方で画一的な標 準横断形で水際部に工夫がみられないなどの課題が残る ものも多くみられていた2).そのため，2006年に「多自 然川づくり基本指針」が新たに定められ，抜本的見直し が行われた3)。この指針では，実施の基本として，自然 の特性やメカニズムの活用, 生物の生息・生育・繁殖環 境の保全・創出, 河川全体の自然の営みや地域の暮ら し・歴史・文化及び河川管理全般を視野に入れた川づく りなどが挙げられ，中長期的に解決すべき課題として， 水際の適切な河岸工法に関する技術開発の必要性などが 提言されだ3.
島谷ら ${ }^{4)}$ は，河川改修による直線化が，瀬・淵構造の 変化, 植生の減少, 河床の単純化等の生物生息空間の単 純化をまねき，魚類の生息に影響を及ぼすことを報告し ている. 他にも河川水際（水辺エコトーン）の形状や植 生の違いが魚類・底生生物の生息に及ぼす効果等の研究 事例が近年多くみられるようになり5),6，水際環境の多様 性が生物の生息空間及び生息する生物の多様性に大きく 貢献していることが明らかになってきている.しかし， これらの研究は河川の中・上流域を対象にしたものがほ とんどである. 河川感潮域においては, 水質, 地盤高, 底質などと底生生物の分布についての研究事例はあるも のの ${ }^{7,8,9,9,10)}$ ，河岸の整備手法に着目して，底生生物の生 息実態から評価を行った事例は我が国では見当たらない． そこで本論文では，河川感潮域に覆土によって整備さ れた緩勾配の河岸と従来型の急勾配の石積護岸を対象に 
（図-1），それぞれの物理環境之底生生物の特性及びそ れらの相互関係を解析し, 緩勾配河岸の多自然川づくり における効果を評価した。

\section{2. 調査方法}

\section{（1）調査対象地区の概要}

調査対象地区は，図-2に示寸宮崎県延岡市を流れる 五ヶ瀬川の河口から3.4 4.1km地点に位置する感潮域で ある．本地区は延岡市の中心街にあたり，2005年9月の 台風14号による浸水被害を受け，五ケ瀬川激甚災害特別 緊急事業による河道掘削及び護岸改修等が行われた。

右岸側は北町・本小路地区と呼ばれ，周囲に城跡や歴 史的な施設である畳堤や水神があり，高水敷きでは流れ 灌頂 (灯籠流し) や大祐式 (神事) などの行事が行われ ていた，そのため，地域の風土・文化に配慮した親水空 間の整備が行われた ${ }^{11)}$.

整備区間には，図-1に示したような石積護岸を覆土し た緩勾配河岸と，覆土をしていない従来型護岸の整備手 法の異なる2区間がある．緩勾配河岸の前面は干潮時に は底泥の一部が干出して干潟となるが，石積護岸では水 深が浅くなる程度で底泥は干出しない.

\section{（2）調査地点}

従来型護岸区間の調査ラインとして，岸際の水深が深 く，河床の横断形状が平坦であるという従来型護岸の特 徵が明瞭な上・下流の水制間のほぼ中央にB1ラインを 設定した（図-3）.

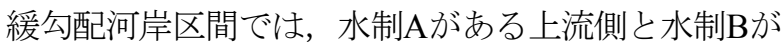
ある下流側では河岸の横断勾配と河床材料に外観上の違 いが認められたため，それぞれに調査ラインを設定した. 各調査ラインは，潮間帯が横断方向に長いという緩勾配 河岸の特徵が明瞭な水制周辺とし，水制の影響で地盤高 や河床材料が複雑に変化する水制近傍の特異点を除いた 中から，代表的なA2及びA3ラインを選定した（図-3）。

各ラインにおいて調査地点を一定の間隔で9〜 12点設 定した（図-3）。ただし，調查時期はA2-4〜A2-8，B1-6 〜B1-9, A3-3〜A3-7は冬季と夏季の2回，その他の地点 は夏季のみである. B1-1〜B1-5は石積部で，地盤高はそ れぞれA3-1〜A3-5に対応させて設定した.

\section{（3）調査方法}

\section{a) 物理環境調査}

各地点の中央部（図-3の拡大図の中の(2)列）で河床材 料を深さ $10 \mathrm{~cm}$ 採取し，持ち帰って粒度組成，有機物量 の指標となる強熱減量をそれぞれJIS-A1204，JIS-A1226 に従い分析した. また，各地点の地盤高を水準測量した.

調査日は冬季が2008年12月8日，夏季が2009年6月17日， 18日で，いずれも干潮時（最干潮位 T.P.-0.26m）に調查

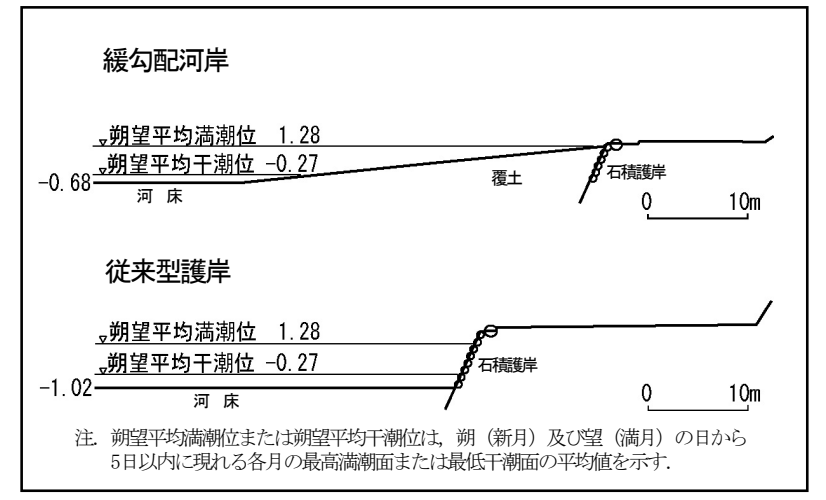

図-1＼cjkstart調査対象地点における河岸の横断形状概略

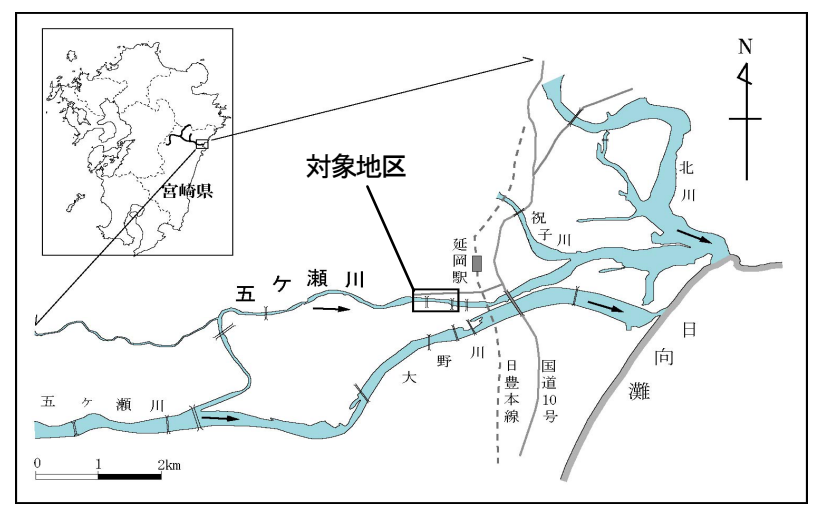

図-2 調査対象地区の位置
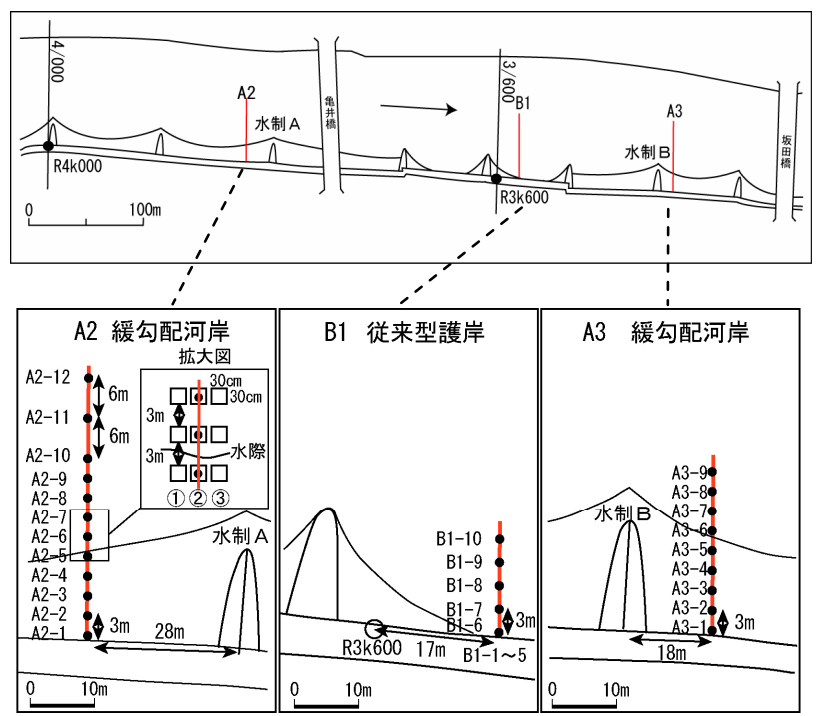

図-3 調査ライン及び調査地点

した.

\section{b) 底生生物調査}

物理環境調査と同日に各地点の3箇所（図-3の(1)，(2), (3)列) に $30 \mathrm{~cm} \times 30 \mathrm{~cm}$ のコドラートを設置し，コドラー 卜内の深さ約 $10 \mathrm{~cm}$ ま゙の底生生物を河床材料とともに スコップで採取した。水没部では，底生生物の流失を防 止するために網目 $1 \mathrm{~mm} \times 1 \mathrm{~mm}$ のサーバーネット付のコ ドラートを用いた．採取試料は $70 \%$ のエタノールで固定 して実験室に持ち帰った後, 種類別個体数を計数した. このほか，夏季調査では，従来型護岸の岩上や岩の間に 
潜んでいる生物を冬季と同様にコドラートを用いて定量 採取した. こうして得られた採集箇所別の計数結果を各 ラインの(1)，(2)，(3)の列ごとに集計し，ライン別の平均 種類数, 平均個体数, 及び多様度指数として個体数によ る変動が小さいとされる森下の $\beta$ 指数 ${ }^{12)}$ を計算した.

\section{（4）解析方法}

緩勾配河岸と従来型護岸における物理環境の違い，及 び底生生物相と物理環境との関係を明らかにするために 統計解析を行った. 解析には, 以下のクラスター分析と 正準対応分析を行った.

\section{a)クラスター分析}

各地点の物理環境の特性を把握するために, 調査した 地盤高，中央粒径，強熱減量によるクラスター分析を ユークリッド平方距離に基づくウォード法により行った. 分析にはCRANのWebサイト (http://www.r-project.org/) からダウンロードできるフリー統計ソフトRを使用した. 地盤高, 中央粒径, 強熱減量の各データは, 標準化 (平 均值0, 標準偏差 1）して使用した.

b) 正準対応分析 (CCA)

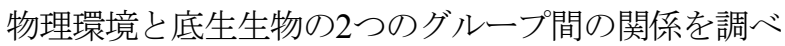
るために, 正準対応分析 (Canonical Correspondence Analysis）を行った. 使用したデータは2009年夏季調査 の結果（石積部のB1-1〜B1-5を除く）で, 独立変数とし て強熱減量，中央粒径，地盤高の各地点の測定データを， 従属変数として3地点以上で出現した底生生物 23 種の地 点別個体数を対数変換 $(\log (\mathrm{x}+1))$ して与えた. 解析に は統計処理ソフトのPC-ORDver.5を使用した。

\section{3. 調査結果及び考察}

\section{（1）物理環境調査結果}

各ラインの横断形状を比較すると，図-4に示すように 従来型護岸のB1ラインは護岸際から平坦河床となって いた. 緩勾配河岸のA2ラインは, A3ラインに比べて傾 斜が緩やかであった，潮間帯は，その範囲を朔望平均満 潮位から朔望平均干潮位までとすると，A2ラインは護 岸から15m，A3ラインは護岸から10m付近までで，B1ラ インは護岸の石積部のみで干潟は出現しない.

河床材料をライン間で比較すると，図-5に示すように 平坦河床のB1ラインは, 夏季のB1-9の結果を除けば石 積部直下から沖側に強熱減量の高い，中央粒径 $1 \mathrm{~mm}$ 以下 の細粒土が広がっていた．A2ラインは潮間帯が主に硴 床で，潮下帯が細粒土となっていた．A2より勾配の大 きなA3ラインは全地点が概数碩床で，地点による粒径 の差が大きいのが特徴であった．緩勾配河岸のA2及び A3ラインは, ともに従来型護岸のB1ラインに比べて地 盤高, 中央粒径, 強熱減量が横断方向に連続的に変化し ていた.

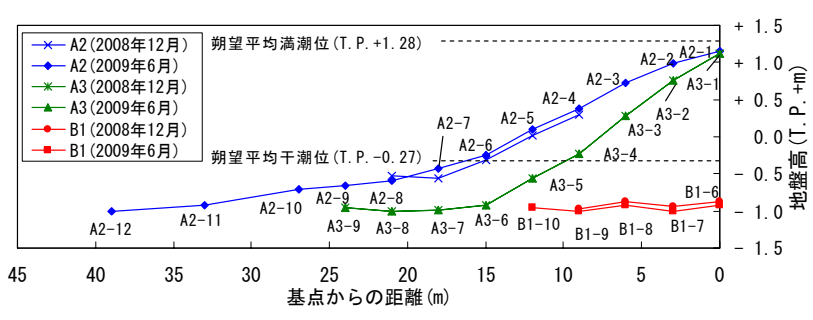

図-4 地盤高調査結果
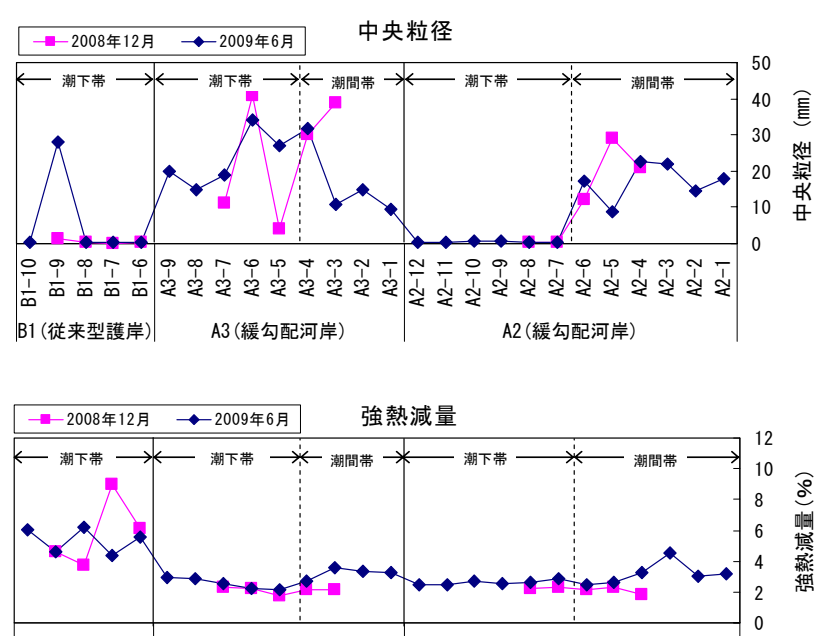

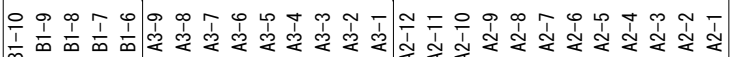

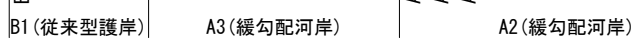

図-5 河床材料の中央粒径 · 強熱減量の横断分布
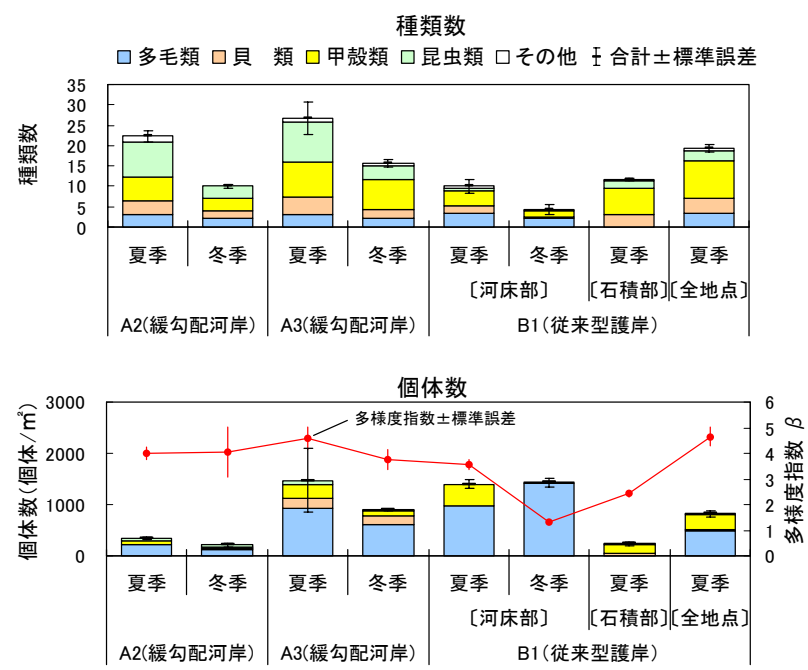

図-6 底生生物の調査ライン別出現状況

\section{（2）底生生物調査結果}

種類数は，図-6に示すように各ラインとも夏季が冬季 に比べて多かった。 また, 両季とも緩勾配河岸のA2ラ イン及びA3ラインの種類数が, 従来型護岸のB1ライン の河床部に比べて多かった（検定， $\mathrm{p}<0.05 ）$ 。しかし， B1ライン河床部の夏季に石積部の結果を加えると, 夏 季の種類数にライン間の差はみられなかった（t検定， $\mathrm{p}>0.05$ ） . 夏季の緩勾配河岸における種類の多さは主に 
昆虫類，B1ライン石積部における種類の多さは主に甲 殼類によるものであった.

ライン別平均個体数は，A2ラインがA3ライン及びB1 ライン河床部に比べて少なかった（検定， $\mathrm{p}<0.01 ）$ 。こ れは主に多毛類の個体数の差によるものである.

多様度指数は, 両季ともB1河床部がA2及びA3ライン に比べて低い傾向がみられたが，有意差が認められたの は冬季のみであった（検定， $\mathrm{P}<0.01 ）$.

\section{（3）クラスター分析結果}

クラスター分析の結果, 図-7に示寸ように各地点は大 きく4つのグループに分類できた. これらをtype1〜type4 として, 地盤高, 中央粒径, 強熱減量の平均值を表-1に 示す. 各typeの特徵をみると, type1は地盤高が低く中央 粒径が小さい. type2は地盤高が高く中央粒径が大きい. type3は地盤高が低く中央粒径が小さい。 type4は地盤高 が低く, 中央粒径が大きい. typel と type3の違いは, type1は強熱減量がtype3より大きいことである。また， 従来型護岸の河床部のB1-6〜B1-10は，B1-9を除くとす べての地点がtype1に属していることから，横断方向に 物理環境が類似していることがわかる.

従来型護岸の河床部からなるtype1は，図-8に示寸よ うに主に緩勾配河岸からなるtype2〜4と比較して多毛類 の種類数が多く, 昆虫類が少ない. 一方, 主に緩勾配河 岸の潮間帯部から構成されるtype2は，その沖側の河床 部から構成されるtype3，4 と比較して昆虫類が多く, 多 毛類・甲殼類が少ない. また，それらの差はtype1 との 差よりも大きい. したがって, 底生生物相からみると, 主に河床部からなるtype1, type3, type4は主に潮間帯部 からなるtype2に比べて類似性が高いと考えられる.

\section{(4) 正準相関分析結果}

正準相関分析（CCA）の結果を図-9に示す．A2及び A3ラインの地点は図中に散らばって位置しており，物 理環境の多様性が高いことを示している。一方で，B1-6 〜B1-10は河川横断方向に物理環境の変化が小さいため, 強熱減量が高く中央粒径が小さく地盤高が低い，という 図の右上に集中して位置している.A2ラインの潮下帯 に位置する地点のA2-7〜A2-12も，B1-6〜B1-10に比べて 強熱減量は小さいものの，中央粒径が小さく地盤高が低 いため右上に位置している.

図上にプロットされた底生生物は，大きく(1)～(3)の3 つのグループに分けられた．グループ11はカワゴカイ属 やへテロマスタス属などの多毛類及びニッポンドロソコ エビやカマカヨコエビ属などの甲殸類からなる。 これら は地盤高が低い場所で中央粒径が小さく強熱減量が大き い場所に主に生息しているものと考えられる.グループ (2)は主に昆虫類からなり，地盤高の高い潮間帯を主な生 息場としているものと考えられるが，潮間帯の中では 図-9に示すように地盤高の軸に沿って散らばって分布し

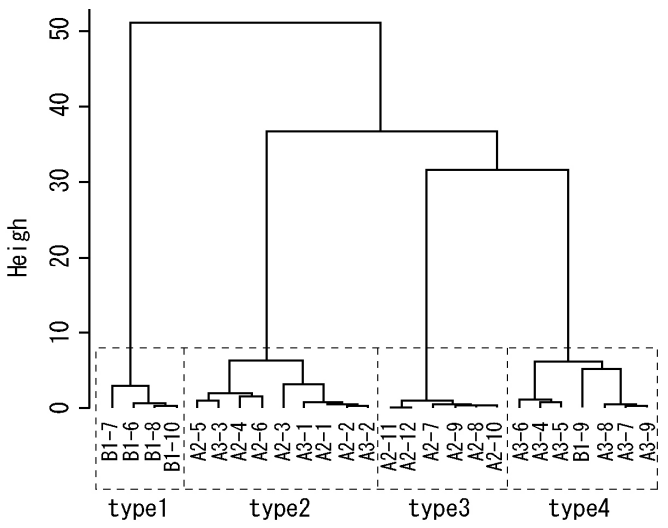

図-7 物理環境による調査地点の クラスター分析結果

表-1 物理環境のtype別平均値

\begin{tabular}{l|rrrr} 
& \multicolumn{1}{|c}{} & \multicolumn{2}{c}{ (平均値士標準誤差) } \\
\hline & \multicolumn{1}{c}{ type1 } & \multicolumn{1}{c}{ type2 } & \multicolumn{1}{c}{ type3 } & \multicolumn{1}{c}{ type4 } \\
\hline 強熱減量 $(\%)$ & $5.54 \pm 0.72$ & $3.27 \pm 0.55$ & $2.6 \pm 0.14$ & $2.86 \pm 0.76$ \\
中央粒径 $(\mathrm{mm})$ & $0.37 \pm 0.07$ & $15.32 \pm 4.79$ & $0.45 \pm 0.07$ & $24.97 \pm 6.65$ \\
地盤高(T.P.+m) & $-0.95 \pm 0.08$ & $0.58 \pm 0.46$ & $-0.72 \pm 0.2$ & $-0.81 \pm 0.28$ \\
\hline
\end{tabular}

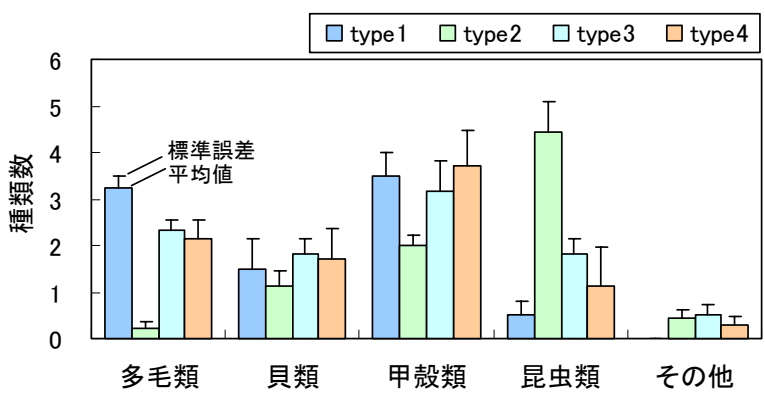

図-8 物理環境type別の底生生物種類数

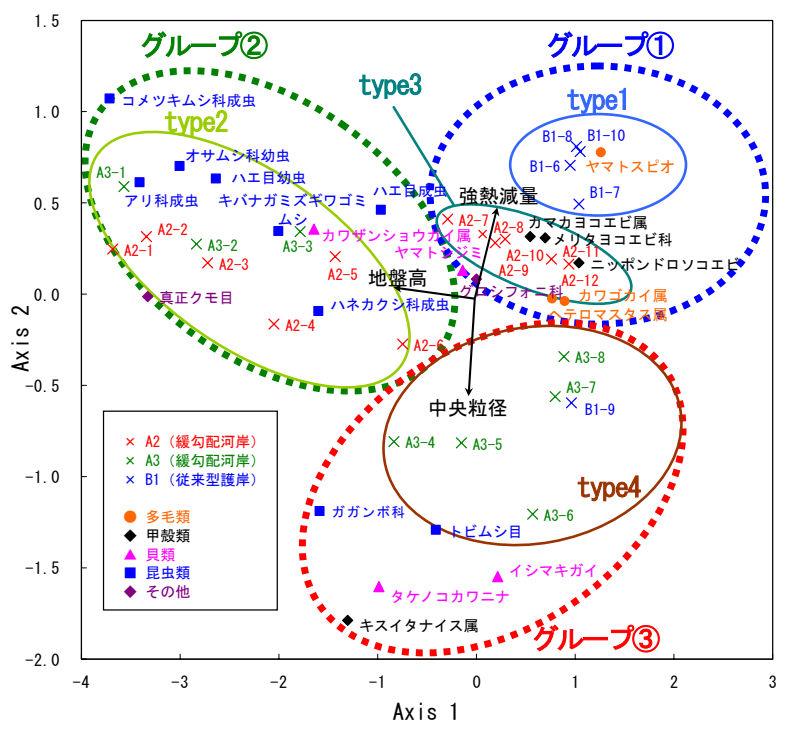

図-9 CCA分析結果

ており，種類によって好む地盤高が異なるものと考えら れる.グループ(3)は央粒径が大きく強熱減量が小さい 場所を好む種類が生息しているものと考えられ，一般に 
砂泥質から泥質を好む多毛類が少ないのが特徴である.

以上のことから，河川の底層を生息場として利用する 底生生物も，種によって好むマイクロハビタットスケー ルの生息環境が異なることがわかる.

\section{（5）緩勾配河岸の底生生物による評価}

緩勾配河岸のA2，A3ラインが従来型護岸のB1河床部 より種類数が多かった（図-6）。この要因は，図-9に示 すように地盤高の高い潮間帯の磎床, 物理環境の分類で はtype2に昆虫類が多く生息していたためと考えられる. 中でもトビムシ目，コウチュウ目に属する地表性昆虫の 種類数が昆虫類全体の約半数を占めていた（表-2）.

新井ら ${ }^{13)}$ によると，地表性昆虫の中では，トビムシ目 やコウチュウ目で潮間帯に進出した種類が多いとされて おり，潮間帯に進出した地表性昆虫の生息場として緩勾 配河岸が重要であることが示唆される.

本調査で確認された表-2に示寸昆虫類の中には, 絶滅 危惧種3種が含まれていた，そのうち1種はキバナガミズ ギワゴミムシであり, 埼玉県で絶滅, 大阪府ほか 1 道5県 で絶滅危惧種等の希少種に指定されている。本種は，従 来型護岸の河床部でも確認はされているが，緩勾配河岸 の潮間帯部での個体数が多かった．また，大阪府の絶滅 危惧 I 類を初めとして合計5県で希少種に挙げられてい るウミミズギワゴミムシは, 緩勾配河岸の潮間帯のみで 採取されている. 残る1種で緩勾配河岸の潮間帯のみで 採取されたクロシオガムシは，環境省のレッドリストで 準絶滅危惧種に指定されている。これらの種は，いずれ も河口や海岸などの潮間帯に生息する種である ${ }^{14,15), 16}$. キバナガミズギワゴミムシは，満潮時には水没する小石 や綑の下に潜み，干潮時に干潟上に現れて活動するとさ れ ${ }^{15)}$, 減少原因として護岸工事等の河川改修, 干潟の縮 小や水質污濁の影響が挙げられている ${ }^{14,155,16)}$. 中島ら ${ }^{17)}$ も同じ五ヶ瀬川水系の支川である北川感潮域の人工ワン ドで，クロシオガムシとキバナガミズギワゴミムシを確 認しており，両種が造成された $1 / 5$ 勾配の斜面に生息し ていたことから，傾斜角をつけた掘削の重要性を指摘し ている.このほかハネカクシ科及びハサミムシ目の成虫 が緩勾配河岸のみで確認された。 海外では, 同じ八ネカ クシ科のナギサ八ネカクシ属の一種が，干潮時に干潟の 砂の上や石の下，岩礁の砂の隙間から発見され ${ }^{18)}$ ，干潮 時に砂の表面に現れてヨコエビを捕食することなど ${ }^{99)}$, 潮間帯を隠れ家や餌場などの重要な生息場の一部として 利用していることがわかっている.

以上のように, 潮間帯の緩勾配部は昆虫類，とりわけ 潮間帯に進出した地表性昆虫類にとって重要な生息場で あり，護岸工事などにより全国各地で減少しているもの と危惧される。

従来型護岸のB1石積部では, 緩勾配河岸の潮間帯に 比べて甲款類の種類数が多く, 石積部を含めると, 従来 型護岸と緩勾配河岸との間に種類数及び多様度指数に差
表-2 底生生物調査結果（夏季·冬季の平均）

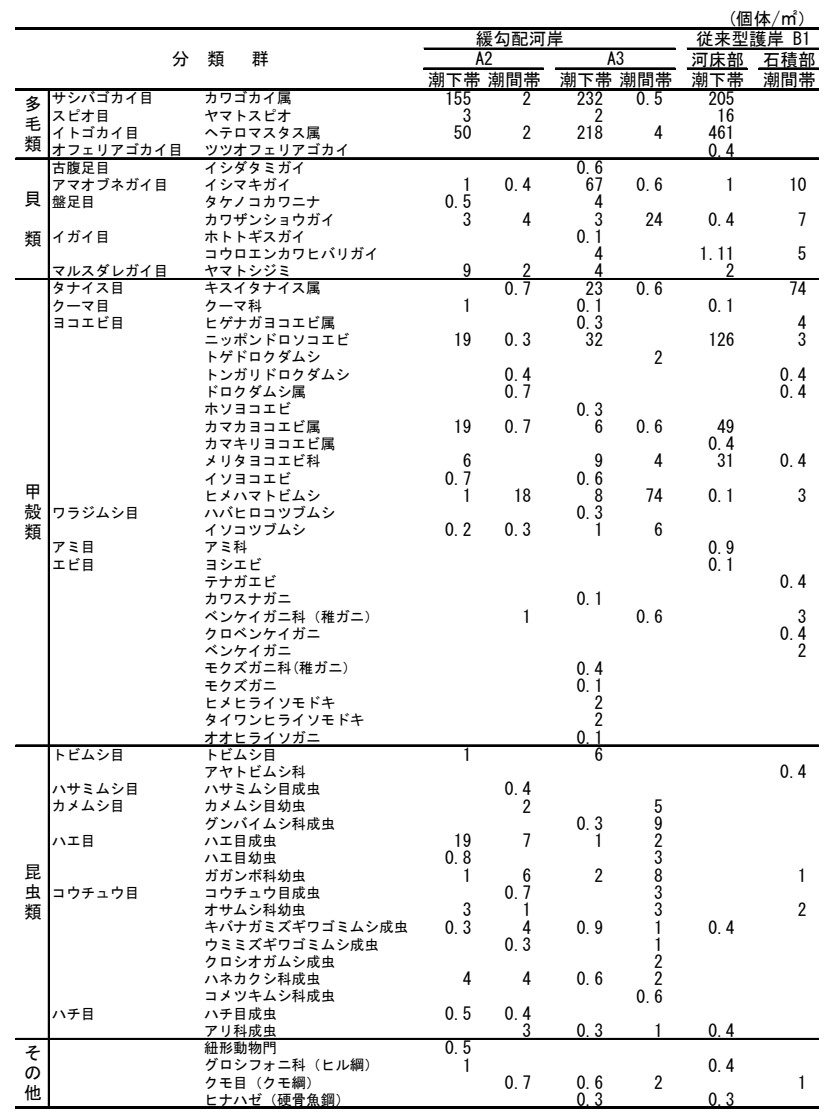

はみられなかった（図-6）。石積部のみで出現した甲款 類は，テナガエビ， ベンケイガニ，クロベンケイガニな どである（表-2）。テナガエビは磒下や礫間に日中隠れ， 夜間にはい出て餌をとる20). ベンケイガニ類 2 種は，土 手の堅い泥地に巣穴を掘って生活寸る習性があり ${ }^{21)}$, 石 積護岸の石の間から土手に巣穴を形成しているものと考 えられる. ベンケイガニは6県で，クロベンケイガニは3 県で希少種となっており, 護岸のコンリート化などが減 少原因と考えられている22). したがって，これらの従来 型護岸石積部での生息は，コンクリート化していない空 石積護岸の効果と類推される.

潮下帯では，図-9に示したCCA分析結果によると，底 生生物は底質の粒径及び強熱減量の大小によってグルー プ(1)と(3)に分けられた. これは既存研究7,8)などで示され ているように底生生物の分布が底質環境と関係が高いた めと考えられる. 表-2に示した底生生物の出現状況から みると，A3ラインでは他のラインと比べて礫またはコ ンクリート護岸に付着するイシマキガイが多い. 砂間や 礫下に生息するカワスナガニ, オオヒライソガニ, タイ ワンヒライソモドキ, ヒメヒライソモドキ, モクズガニ もA3ラインのみで出現しており, 礫の存在がA3ライン の生物相を特徽つけけいる. これらカニ類のうち, カワ スナガニが環境省の準絶滅危惧に指定されているほか, オオヒライソガニを除く 4 種とも2 6県で希少種に指定 されている.このことは, 適度な緩勾配河岸の整備に 
よって，河床材料の多様性と失われた希少種の生息環境 の創出が可能であることを示唆する.

以上のことから, 緩勾配河岸は, 従来型護岸河床部よ りも物理環境, 生物相ともに多様性に富み, 希少種に とっても重要な生息場であると推察される.

\section{4. 結論}

本研究では，覆士によって整備した緩勾配河岸と，従 来型の石積夕護岸における物理環境(地盤高, 河床材料 の粒径・強熱減量) と底生生物を調査し, 両整備手法に おける底生生物相の特性と物理環境との関係，及び多自 然川づくりにおける緩勾配河岸の効果を検討した. 研究 結果は次のとおりである.

・ 緩勾配河岸は, 従来型護岸に比べて地盤高, 中央粒 径，強熱減量が横断方向に連続的に変化していた.

・ 緩勾配河岸は, 従来型護岸の河床部に比べて底生生 物の種類数が多かった. 特に昆虫類が多かった.

・緩勾配河岸で昆虫類が多かったのは，これらが好む 地盤高の高い潮間帯が存在したためと考えられる.

- 底生生物の種類によって好適な物理環境条件が異 なっており, 緩勾配河岸における底生生物の種類の 豊富さは，物理環境の連続した変化にともなう多様 性の高さによるものと考えられる.

・ 緩勾配河岸のみで確認された希少種も多く, 潮間帯 における緩勾配河岸の重要性を示唆するものと考え られる.

・従来型護岸の石積部では，エビ・カニなどの甲殻類 が多種類生息し，希少種もみられるなど，空石積工 法の効果が類推される.

以上のことから，緩勾配河岸の方が従来型護岸河床 部よりも多様な底生生物を育む河川環境になっており, 河川感潮域における多自然川ら゙くりの整備手法の一つと して，横断方向に連続性を持たせた水辺エコトーンの整 備は底生生物の多様性や希少種の保全の面から効果が期 待できるものと考えられる. ただし, 従来型護岸の空石 積部のみで確認された生物もいることから，このような 生物についても配慮し, 両整備手法をバランス良く配置 することが望ましいと考えられる.

謝辞 : 本研究を進めるにあたり, 底生生物の分類等につ いてご指導いただいた福岡大学工学部社会デザイン工学 科の伊豫岡宏樹助手，（財）九州環境管理協会の宇野潔 氏，道山晶子氏，城内智行氏に心より感謝申し上げる.

\section{参考文献}

1) 島谷幸宏 : 河川環境の保全と復元 一多自然型川づくりの実 際一, 鹿島出版会, 東京, 2000 .

2) 多自然川づくりレビュー委員会 : 多自然川づくりへの展開,
国土交通省河川局記者発表資料，2006.

3）国土交通省河川局 : 多自然川づくり基本指針，記者発表資料, 2006.

4) 島谷幸宏，小栗幸雄，荁場祐一：中小河川改修前後の生物生 息空間と魚類相の変化，水工学論文集，第38巻，pp.337-344， 1994.

5) 内田朝子, 洲崎登子, 山本敏哉, 白金晶子, 藤井泰雄 : 準用 河川太田川自然環境調査報告一多自然型川づくりを用いた河 川整備の評価一, 矢作川研究, No.8, pp.187-217, 2004.

6) 河口洋一: 水辺の植物が河川性魚類の生態に及ぼす影響, 海 洋と生物, 25(6), pp.452-459, 生物研究社, 2003.

7) 土屋誠, 栗原康 : 宮城県蒲生干潟における底生生物の分布々 微細粒子の挙動に関する研究, 生理生態, 17, pp.145-151, 1976.

8) 大谷壮介，上月康則，倉田健悟，仲井薰史，村上仁士 : 河口 干潟潮間帯の物理的な底質環境と底生生物群集との関係，土 木学会論文集G, Vol.63, No.4, pp.195-205, 2007.

9) 品川汐夫, 多部田修: 河口域干潟における底生動物群集の経 年変化についてのRsn法による解析，日本水産学会誌，64(5), pp.796-806, 1998.

10) 山下俊彦，菅沼剛，宮下将典，吉田徹，桜井泉 : 石狩湾新 港から石狩川河口の周辺海域における底質特性とマクロベン トスの群集構造, 海岸工学論文集, 第47巻, pp.1201-1205, 2000.

11) 塚本剛好：五ケ瀬川激甚災害対策特別緊急事業の進渉状況, 九州技報，第45号，2009.

12) 森下正明 : 種多樣性指数值に対するサンプルの大きさの影 響, 日本生態学会誌，46，pp.269-289， 1996.

13) 新井志保, 吉富博之, 丸山宗利 : 日本の潮間帯性甲虫, 昆 虫と自然，39(12), pp.21-24, 2004.

14) 大阪府 : 大阪府における保護上重要な野生生物，2000.

15) 香川県 : 香川県レッドデータブック, 2004.

16) 岡山県 : 岡山県版レッドデータブック2009, 2010.

17) 中島淳, 江口勝久, 乾隆帝, 西田高志, 中谷祐也, 鬼倉徳 雄, 及川信: 宮崎県北川の河川感潮域に造成した人工ワンド における魚類, カ二類, 甲虫類の定着状況, 応用生態工学, 11(2), pp.183-193, 2008.

18) Moore, I. Legner, E. F. \& Chan, T. : A review of the genus Bryothinusa with description of three new species (Coleoptera : Staphylinidae), Entmological News, 84, pp.73-81, 1973.

19) Moore, I. \& Legner, E. F., Bryothinusa chain, a new species of marine beetle from Hong Kong (Coleoptera : Staphylinidae), Coleopterists Bulletin, 25, pp.107-108, 1971.

20) 奥田重俊，柴田敏隆，島谷幸宏，水野信彦，矢島 稔，山岸 哲 : 川の生物図典，財団法人リバーフロント整備センター編, 山海堂, 東京, 1996.

21) 小野勇一: 干潟のカニの自然史, 平凡社, 東京, 1995.

22) 愛媛県: 愛媛県レッドデータブック, 2003.

（2010. 9. 30受付） 